\title{
CIVIC ENGAGEMENT IN A DIGITAL TIME - IS THERE A DIVIDE IN TERMS OF SOCIAL CIVIC BEHAVIOR?
}

\author{
Adriana Zait, ${ }^{1}$ Andreia Gabriela Andrei ${ }^{2}$ \\ and Ioana Alexandra Horodnic ${ }^{3}$
}

\begin{abstract}
ICT's and social media dramatically reshape the way citizens communicate and get involved into the civic life of a city and country. As a consequence of these developments, we would expect people to be more engaged citizens, active participants in both their online and offline communities. However, two questions arise: do people actually become more civic minded due to the digital evolution? Does social involvement in online virtual communities translate into real life actions? Answering these questions is the aim of the present study, which intends to analyze if there is a divide in terms of social civic behavior on two axes - attitude towards civic engagement and stated civic participation, online and offline behavior. We used survey as main research method in order to answer our research questions, and the study is a descriptive one. The investigated population consisted of a purposive sample of internet users from cities with possible different degrees of civic attitude (measured through a classical Civic Engagement Scale).
\end{abstract}

Key words: civic engagement, civic attitude, offline and online civic participation, stated civic behavior.

\section{Introduction: context and theoretical background}

The starting point of our study was the increasing importance of civic values and civic participation for the modern economy and society. The huge importance of people's involvement in all aspects of economic and especially societal life, through various civic actions, was recognized through the development of new models, like the quadruple helix, in which civism plays a major role: industry academic environment - government - civil society [32], [33]. The civil society can act as catalyst, accelerator, guardian and helmsman, at the same time, leading to synergic effects between all economic and social actors. The social capital obtained through civic participation produces economic growth effects, as previous research showed [44], and leads to new participatory models [42], to the development of the field of various and complex civic services [10] and to a new type of economy, something that can be labeled a real "economy of engagement" [25]. In such a civic engaged economy, new mechanisms of communication and participation can change the way in which the entire society functions. Although it might sound like a big word, this change can be dramatic, as noticed by Kleinhans, van Ham and Evans-Cowley [30], when they refer to the organized demonstrations in Egypt (the Arab Spring) or those of riots in London and Manchester, 2011. Not at all less dramatic were the demonstrations against corruption organized in Bucharest and several other big Romanian cities, in January - February 2017. All these manifestations have in

\footnotetext{
${ }^{1}$ Faculty of Economics and Business Administration, University “Alexandru Ioan Cuza” Iasi, Romania

2 Department of Interdisciplinary Social Research, University “Alexandru Ioan Cuza" Iasi, Romania

${ }^{3}$ Faculty of Economics and Business Administration, University “Alexandru Ioan Cuza" Iasi, Romania
} 
common ICTs and social media as powerful tools for citizens' quick mobilization and selforganization.

Civic education and civic engagement lead to youth empowerment and long term positive effects on various economic and social issues - wellbeing, intelligence, creativity and innovation, democratic values and behavior, happiness - and all these contribute to personal growth and economic development [1], [2], [3], [14], [28], [31]. Participation and civic engagement are associated with psycho-sociological wellbeing, social intelligence, social innovation, democracy supportive behaviors or happier societies [14], [15], [25], [36], [41], [46]. Effects are found on various levels academic, personal, social and citizenship level outcomes [8]. All these lead, in the end, to a better quality of life, as a terminal or end value, through a simple mechanism similar to that described by Zanoli and Naspetti [49] for something very pragmatic, like organic food. For example, if we get involved in civic issues, we can fight for concrete attributes, like school abandon, get to abstract attributes, such as better educated people or better democracy, obtain functional competences or consequences, such as ability for continuous learning or ability to understand societal issues; one step further, this leads us to psycho-social consequences, like feeling good, and then to obtaining instrumental values, such as own physical and mental health, translated finally to a higher quality of our life.

Numerous factors influence civic engagement, at both individual and social group level. Some of the previous studies focused on personal factors [9], [35], [39], while other analyzed educational or cultural factors [4], [25], [39], [48]. Among all these factors, social media seem to have a significant impact on all aspects of life, including societal issues and civic participation [5], [27], [37], [43], [47], [50]. Although the effects of internet and social media on civic engagement and participation are mostly positive, not all dimensions of internet use are linked to civic engagement [37], and there might be thresholds in internet use - as previous investigators noticed, the time spent online has the potential to actually erode social capital [43], thus having a negative effect. The relationship between democracy and Internet is controversial [6], but Internet could become a less coerced public sphere and a place for fruitful debates, despite inherent risks of fake news or manipulation. Social media seems to play a very important role especially for cynics and skeptics [5], who rely more on citizen generated news, specific for social networks.

Encouraging and supporting civic attitudes and engagement seem an undisputable desiderate. However, the positive civic attitude is not enough, because positive attitudes towards civic engagement do not necessarily translate into real life actions - real civic behavior. There is a rather normal human gap between attitude and behavior [38], [45]. Efforts for measuring civic attitude, civic competence and civic behavior were made, all over the world, and sometimes large differences across countries, persistent in time, were found [21], [22], [23], [34], suggesting that situational factors, besides cultural ones, exercit an influence, as well.

Resuming the logical framework of our study in just a few words, civic attitude and engagement are important present issues; their influence factors need to be known; effects on various economic and social aspects are significant, and large differences are found in different countries; there is a gap between civic attitude and civic behavior, and social media is a common mediator, plays an important role in all these subjects. This is the general context in which our main research questions were raised: Do people become more civic minded due to the digital evolution? Does social involvement in online virtual communities translate into real life actions? Answering these questions is the aim of the present study, which intends to analyze if there is a divide in terms of 
social civic behavior on two axes - attitude towards civic engagement and stated civic participation, online and offline behavior.

\section{Objectives and methodology}

The main objectives of our study were, at this stage, descriptive ones, namely to measure the stated general civic behavior of an Eastern European Country, EU member, to find out potential relationships between online civic engagement (online_CE), offline civic engagement (offline_CE), civic attitude (CEA) and the stated general civic behavior (CEB), to analyze the results and use them for a future explanatory research.

We assume positive relationships between online civic engagement and civic engagement attitude (Hypothesis1), between civic engagement attitude and general civic engagement behavior (Hypothesis 2), as well as between both online and offline civic engagement and civic engagement behavior (Hypotheses 3 and 4): (H1) online_CE $\rightarrow$ CEA; (H2) CEA $\rightarrow$ CEB; (H3) online_CE $\rightarrow$ $\mathrm{CEB}$; (H4) offline_CE $\rightarrow$ CEB.

Following aforementioned study objectives, as well as literature indications, we developed and tested a research model (fig.1), using structural equation modeling (PLS-SEM method) for data analysis, and a questionnaire based survey administered online on a convenience sample for data collection.

The questionnaire contained 22 items for measuring the four constructs of interest ( $\mathrm{CEB}$, CEA, online_CE, offline_CE) as follows: 8 items for measuring CEA - civic engagement attitude and 6 items for measuring CEB - engagement behavior (taken from the Civic Engagement Scale of Doolittle and Faul, [12], as well as 3 items for measuring the stated offline civic engagement (offline_CE) and 5 items for measuring the stated online civic engagement (online_CE) adapted from the Online Civic Engagement and Offline Civic Engagement scales of Jugert et al. [27]. Although Jugert et al have used larger scales for offline and online civic engagement, after carefully analyzing the items and talking to 3 experts, we decided to clearly separate online and offline based on the final civic action, not on the channel of information or transmission; from this perspective, for example, money donations or volunteering can be done both entirely or partially offline and online. Therefore, we retained only two items specific for entirely offline and added an item which separated respondents in NGO members and non-members. Also, on the online civic engagement we added one item for measuring the stated perceived easiness of online versus offline civic participation. To these items we added profile questions and demographics: type of social network used, place of residence, gender, age, civil status, revenue, work experience and field of studies.

The 8 items for CEA - civic engagement attitude were I feel responsible for my community, I believe I should make a difference in my community, I believe that I have a responsibility to help the poor and the hungry, I am committed to serve in my community, I believe that all citizens have a responsibility to their community, I believe that it is important to be informed of community issues, I believe that it is important to volunteer, I believe that it is important to financially support charitable organizations.

The 6 items used for measuring CEB - general civic engagement behavior were: I am involved in structured volunteer position(s) in the community, When working with others, I make positive changes in the community, I help members of my community, I stay informed of events in my 
community, I participate in discussions that raise issues of social responsibility, I contribute to charitable organizations within the community.

The 5 items for measuring online civic engagement (online_CE) were: I liked or shared link news, music or video with a social or civic content to my contacts, I discussed societal or civic contents on the net, I participated in online based petition, protest or boycott, I've visited websites of civic organizations, In general, I consider that is easier to participate or support civic actions online than offline.

Finally, 3 items were used for the offline civic engagement (offline_CE): I've worn bracelets or any other type of symbol of support for civic and social cases, I've taken part in a physical, offline demonstration, I am (or I used to be) an active member of a civic, non-profit organization.

All 22 items were measured on Likert type scales with 5 steps. The questionnaire was administered in Romanian, after a content validation process of back translation, in order to ensure the appropriate connotations. We used Google forms for the survey, and the questionnaire was distributed both on Facebook and to a list of e-mails. The data was collected during a week, in January 2017.

\section{Results and discussion}

We obtained a sample of 217 complete answers, with the following structure of respondents: 27.1 $\%$ males and $72.9 \%$ females; $73.4 \%$ age $18-25$ years, $17.4 \%$ age $26-35$ years; $88.5 \%$ higher education degree; $47.7 \%$ have been NGO members. The majority of the sample consists of students with a background in economic and social studies. This can be explained by the fact that we used the Facebook accounts of the authors, who are academics and have many former student connections; also, the e-mails were sent to former students, with the kind request of distributing the questionnaire to their friends, as well - we especially targeted youth. Although a convenience or purposive sample, not representative for the whole population, it is a good pilot for our descriptive research.

Complying with PLS-SEM methodology [20] for testing the four assumptions included in the research model regarding the positive effects: (H1) online_CE $\rightarrow$ CEA; (H2) CEA $\rightarrow$ CEB; $(\mathrm{H} 3)$ online_CE $\rightarrow$ CEB; (H4) offline_CE $\rightarrow$ CEB, the overall goodness of fit, measurement model and structural model were evaluated, and relationships between variables were reported as outlined in fig.1. Model evaluation indicated the overall goodness-of-fit (GoF), the value of SRMR (SRMR= 0.075 ) being below the 0.08 limit of $\mathrm{Hu}$ and Bentler [24], as recommended for PLS-SEM method.

Also, the measurement model complied to the reliability and validity requirements, all reflective constructs $(\alpha>0.7$; rho_A $>0.7$; CR $>0.8$; AVE $>0.5$ detailed in Table 1$)$, as well as composite constructs (no collinearity among indicators) fulfilling methodological criteria. 


\begin{tabular}{|l|l|l|l|l|}
\hline Construct & $\boldsymbol{\alpha}$ & rho_A & CR & AVE \\
\hline $\begin{array}{l}\text { CEA } \\
\text { [composite: the sum-scores of the 8 items measuring CEA] }\end{array}$ & 1.000 & 1.000 & 1.000 & 1.000 \\
\hline $\begin{array}{l}\text { CEB } \\
\text { [reflective: } 6 \text { items] }\end{array}$ & 0.867 & 0.877 & 0.900 & 0.602 \\
\hline $\begin{array}{l}\text { offline_CE } \\
\text { [composite: } 3 \text { items] }\end{array}$ & - & 1.000 & - & - \\
\hline $\begin{array}{l}\text {-online_CE } \\
\text { [reflective: } 5 \text { items] }\end{array}$ & 0.838 & 0.876 & 0.883 & 0.605 \\
\hline
\end{tabular}

Table 1: Construct Reliability and Validity

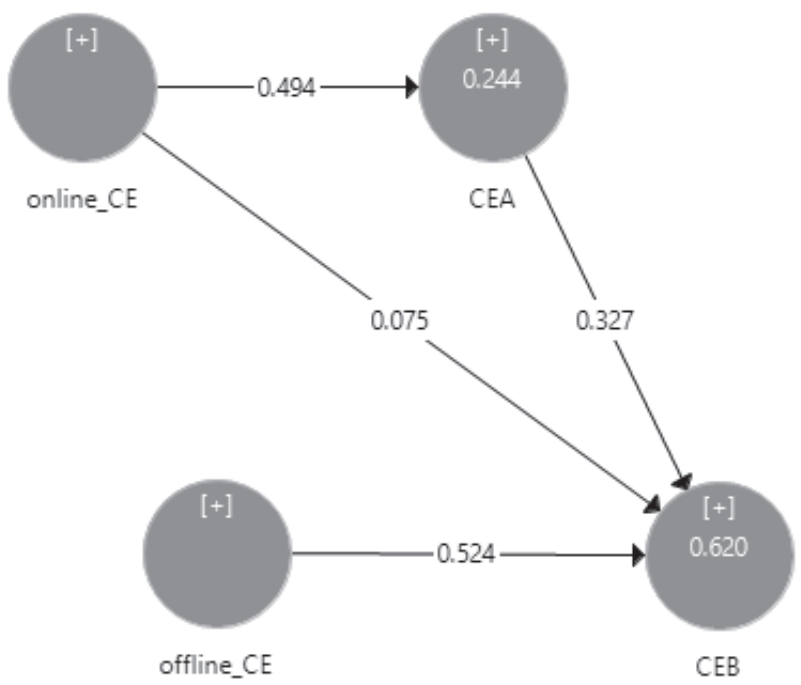

Figure 1: Research model with determination coefficients and path values

As indicated by Diamantopoulos and Siguaw [11], the variance inflation VIF $<3.3$ indicated no multicollinearity among latent variables. Discriminant validity criteria of Fornell and Larcker [16] were meet (detailed statistics in Table 2) and HTMT values (Table 3) were below 0.85 as indicated in Henseler et al [19], [20].

\begin{tabular}{|l|l|l|l|l|}
\hline Construct & CEA & CEB & offline_CE & online_CE \\
\hline CEA & $\mathbf{1 . 0 0 0}$ & - & - & - \\
\hline CEB & 0.605 & $\mathbf{0 . 7 7 6}$ & - & - \\
\hline offline_CE & 0.459 & 0.723 & - & - \\
\hline online_CE & 0.494 & 0.578 & 0.652 & $\mathbf{0 . 7 7 8}$ \\
\hline
\end{tabular}

Table 2: Discriminant Validity: Fornell and Larcker criterion 


\begin{tabular}{|l|l|l|l|}
\hline & CEA & CEB & online_CE \\
\hline CEA & & & \\
\hline CEB & 0.645 & & \\
\hline online_CE & 0.512 & 0.629 & \\
\hline
\end{tabular}

Table 3: Discriminant Validity: HTMT criterion

Bootstrapping procedure with 5000 re-samples employed for the structural model evaluation indicated that the relationships included in the model explain $62 \%$ of CEB variance $\left(\mathrm{R}^{2}=0.620\right)$, while $24,4 \%$ of CEA variance is explained by online_CE, as observable from Fig. 1.

Bootstrapping results (Table 4) indicated the significance of the positive influences that were hypothesized, highlighting 3 direct effects: online_CE $\rightarrow C E A ; C E A \rightarrow C E B ;$ offline_CE $\rightarrow C E B(\mathrm{H} 1$, $\mathrm{H} 2$ and $\mathrm{H} 4$ confirm) and the indirect effect online_CE $\rightarrow C E B$ (H3 partially confirms).

In the online_CE $\rightarrow C E B$ relationship, the significance of the indirect effect and the lack of the direct effect highlight the mediator role of CEA, the online civic engagement (online_CE) influencing general civic behaviour (CEB) via civic engagement attitude (CEA), as observable from Table 4 and Figure 1.

\begin{tabular}{|l|l|l|l|l|l|l|l|l|}
\hline Effects & $\begin{array}{l}\text { Effect } \\
\text { Type }\end{array}$ & $\begin{array}{l}\text { Path coef } \\
\boldsymbol{\beta}\end{array}$ & Mean & StDev & T & P & 2.5\% C.I. & 97.5\% C.I. \\
\hline CEA $\rightarrow$ CEB & direct & 0.327 & 0.325 & 0.048 & 6.824 & 0.000 & 0.227 & 0.418 \\
\hline offline_CEA $\rightarrow$ CEB & direct & 0.524 & 0.529 & 0.051 & 10.246 & 0.000 & 0.425 & 0.626 \\
\hline online_CE $\rightarrow$ CEA & direct & 0.494 & 0.496 & 0.054 & 9.087 & 0.000 & 0.385 & 0.597 \\
\hline online_CE $\rightarrow$ CEB & direct & 0.075 & 0.078 & 0.059 & 1.264 & 0.206 & -0.043 & 0.191 \\
\hline online_CE $\rightarrow$ CEB & indirect & 0.162 & 0.161 & 0.030 & 5.326 & 0.000 & 0.105 & 0.224 \\
\hline
\end{tabular}

Table 4: Direct and Indirect Effects

As results outline, while civic engagement attitude and offline civic engagement are directly influencing civic behavior, the online engagement exerts a direct positive effect on civic attitude which mediates the indirect effect of online civic engagement on civic behavior.

Finally, a multigroup analysis (MGA) employed to control for potential differences that might appear due to participant's demographics indicated no significant influences, highlighting that the presented model holds.

\section{Conclusions, limits and further research}

Coming back to our research questions and hypothesized relationships, based on the results of the study we can say that people just partially become more civic minded due to the digital evolution, their attitude being affected more than their stated behavior. Although the online civic engagement positively affects the civic engagement attitude, and civic engagement attitude positively affects civic engagement behavior, the online civic engagement attitude has just an indirect effect on online civic engagement behavior. That is, the online civic engagement affects civic behavior only indirectly, through civic engagement attitude (which acts as a mediating variable). This implies that we could use social media and digital instruments in order to increase positive civic engagement 
attitudes. Social involvement in online virtual communities partially translates into real life actions. The positive effect of offline civic engagement on civic engagement behavior is much stronger. No differences were found based on demographic characteristics of respondents.

The main limit of the present research comes from the non-probabilistic sample, not representative for the total population. Also, the sample was a rather small one. The analyzed population consisted mainly from students, and although previous studies have shown that youth civic engagement is a good predictor for future civic participation, we don't have enough data to describe the situation for other categories of age and education. Thus, the results are specific for an exploratory, pilot type of research.

Future research needs to specifically address other categories of age and education, as well as to include other variables than demographic ones in order to explain civic attitude and civic engagement behavior. A second stream for a future research will focus on the nature of the social capital created through civic engagement. In this respect it would be really interesting to test the type of civic engagement, and see if it is a bonding or bridging type. The term "bonding" refers to the value assigned to social networks between homogeneous groups of people (in terms of age, studies, interests, opinions etc.) and "bridging" refers to that of social networks between socially heterogeneous groups [29]; bonding and bridging ties can lead to different types of social capital, some positive and some negative, based on Putnam's work. [40] Social capital development on the internet via social networking websites tends to be bridging capital [13], but social capital formation through civic engagement is still a new area, and more research is needed. As previous studies have shown, memberships in bridging groups are more strongly linked to positive civic values than those from bonding ones [17]. This is why a future research direction will be to test the bonding or bridging nature of online civic engagement, since the desired result of stimulating civic participation is to obtain positive civic values and effects.

\section{References}

[1] ALTMAN, D. and FEIGHERY, E.: Future directions for youth empowerment: Commentary on application of youth empowerment theory for tobacco control, Heath Education and Behavior, 31 (641), 2004, p. 641-647.

[2] ASTIN, A. W., SAX, L. J. and AVALOS, J.: The Long-Term Effects of Volunteerism During the Undergraduate Years. The Review of Higher Education. 21(2), 1999, p. 187-202.

[3] BRENNAN, M.A. and BARNETT, R.V.: Bridging Community and Youth Development: Exploring Theory, Research, and Application, Community Development, 40:4, 305-310, DOI: 10.1080/15575330903279515, 2009.

[4] BROCKNER, J., CHEN, Y.-R, MANNIX, E. A, LEUNG, K. and SKARLICKI, D. P.: Culture and procedural fairness: When the effects of what you do depend on how you do it, Administrative Science Quarterly, 45, 1, 2000, p. 138-161.

[5] CARR, D.J., BARNIDGE, M., LEE, B.G and TSANG, S.J.: Cynics and Skeptics: Evaluating the Credibility of Mainstream and Citizen Journalism, Journalism \& Mass Communication Quarterly, Vol. 91(3) 452-470, DOI: 10.1177/1077699014538828, 2014. 
[6] CERON, A.: Internet, news and political trust: the difference between social media and online media outlets, Journal of Computer-Mediated Communication, vol.20, 2015, pp. 487-503.

[7] COLLINS, C.R., NEAL, J.W. and NEAL, Z.P.: Transforming Individual Civic Engagement into Community Collective Efficacy: The Role of Bonding Social Capital, Am Journal of Community Psychology, 54, 2014, p. 328-336, DOI 10.1007/s10464-014-9675-x.

[8] CONWAY, J., AMEL, E. and GERWEIN, D.: Teaching and Learning in the Social Context: A Meta-Analysis of Service-Learning's Effects on Academic, Personal, Social and Citizenship Outcomes. Teaching Psychology. 36(4), 2009, p. 233-245.

[9] DAWES, C.T., SETTLE J.E., LOEWEN, P.J., MCGUE, M. and IACONO, W.G.: Genes, psychological traits and civic engagement, Phil. Trans. R. Soc. B 370: 20150015, 2015, http://dx.doi.org/10.1098/rstb.2015.0015.

[10] DEKKER, P.: Civicness: From Civil Society to Civic Services?, Voluntas, 20:220-238, DOI 10.1007/s11266-009-9089-9, 2009.

[11] DIAMANTOPOULOS, A. and SIGUAW, J.A.: Formative versus Reflective Indicators in Organizational Measure Development: A Comparison and Empirical Illustration, British Journal of Management, Vol. 17, No 4, 2006, pp. 263-282.

[12] DOOLITTLE, A. and FAUL, A.C.: Civic Engagement Scale: A Validation Study, SAGE Open, July-September, 1-7, DOI: 10.1177/2158244013495542, 2013, sgo.sagepub.com.

[13] ELLISON, N. B., VITAK, J., GRAY, R. and LAMPE, C.: Cultivating social resources on social network sites: Facebook relationships maintenance behaviors and their role in social capital processes, Journal of Computer-Mediated Communication, vol.19, 2014, pp. 855-870.

[14] FINLEY, A.: The Joy of Learning: The Impact of Civic Engagement on Psychosocial WellBeing, Diversity \& Democracy, Vol.15, Iss.3, 2012.

[15] FINLEY, A.: Civic Learning and Democratic Engagements: A Review of the Literature on Civic Engagement in Post-Secondary Education, Paper prepared for the United States Department of Education as part of Contract: ED-OPE-10-C-0078, 2011.

[16] FORNELL, C. and LARCKER, D.F.: Evaluating structural equation models with unobservable variables and measurement error, Journal of Marketing Research, Vol. 18, No 1, 1981, pp. 39-50.

[17] GEYS, B. and MURDOCH, Z.: Measuring the `Bridging`versus `Bonding` nature of social networks: a proposal for integrating existing mmeasures, Sociology, vol.44, iss.3, 2010, pp. 523-540.

[18] GRIEVE, R. and MAHAR, D.: Can social intelligence be measured? Psychometric properties of the Tromsø Social Intelligence Scale -English Version, The Irish Journal of Psychology, 34:1, p. 1-12, DOI: 10.1080/03033910.2012.737758, 2012. 
[19] HENSELER, J., RINGLE, C.M. and SARSTEDT, M.: A new criterion for assessing discriminant validity in variance-based structural equation modeling, Journal of the Academy of Marketing Science, Vol. 43, No 1, 2015, pp. 115-135.

[20] HENSELER, J., HUBONA, G. and RAY, P.A.: Using PLS path modeling in new technology research: updated guidelines, Industrial Management \& Data Systems, Vol. 116, No 1, 2016, pp. 2-20.

[21] HOSKINS, B., SAISANA, M. and VILLALBA, C.M.H.: Civic Competence of Youth in Europe: Measuring Cross National Variation Through the Creation of a Composite Indicator, Soc Indic Res, 123, 2015, p. 431-457, DOI 10.1007/s11205-014-0746-z.

[22] HOSKINS, B., VILLALBA, C. and SAISANA, M.: Measuring Civic Competence across Europe: 10 years, 2012, on, https://ec.europa.eu/jrc/sites/jrcsh/files/20120618COINCivic CompetenceIndex_Brussels.pdf.

[23] HOSKINS, B., VILLALBA, E., VAN NIJLEN, D. and BARBER, C.: Measuring Civic Competence in Europe, JRC Scientific and Technical Reports, 2008, http://publication.jrc. ec.europa.eu/repository/bitstream/JRC42904/bryonycci_jrc42904_final.pdf

[24] HU, L.T. and BENTLER, P.M.: Cutoff criteria for fit indexes in covariance structure analysis: Conventional criteria versus new alternatives, Structural equation modeling: a multidisciplinary journal, Vol. 6, No 1, 1999, pp. 1-55.

[25] HUDDART, S.: Open Source, Social Innovation and a New Economy of Engagement, Open Source Business Resource, 2008, http://timreview.ca/article/184.

[26] JENNINGS, M.K. and STOKER, L.: Social Trust and Civic Engagement across Time and Generations, Acta Politica, 39, 2004, p. 342-379.

[27] JUGERT, P., ECKSTEIN, K., NOACK, P., KUHN, A. and BENBOW, A.: Offline and Online Civic Engagement among Adolescents and Young Adults from Three Ethnic Groups, $J$ Youth Adolescence, 2013, 42: 123-135, DOI 10.1007/s10964-012-9805-4.

[28] KAHNE, J.E. and SPORTE, S.E.: Developing Citizens: The Impact of Civic Learning Opportunities on Students' Commitment to Civic Participation, American Educational Research Journal,Vol. 45, No. 3, 2008, pp. 738-766, DOI: 10.3102/0002831208316951.

[29] KAWACHI, I., KIM, D. and COUTTS, A. et al: Reconciling the three accounts of social capital. Int J Epidemiol Aug, 33(4), 2004, p. 682-90.

[30] KLEINHANS, R., VAN HAM, M. and EVANS-COWLEY, J.: Using Social Media and Mobile Technologies to Foster Engagement and Self-organisation in Participatory Urban Planning and Neighbourhood Governance., Planning Practice \& Research, vol.30, iss.3, 2015, pp. 237-247.

[31] LENZI, M., VIENO, A., ALTOE, G., SCACCHI, L., PERKINS, D., ZUKAUSKIENE, R. and SANTINELLO, M.: Can Facebook Informational Use Foster Adolescent Civic 
Engagement?, Am J Community Psychol, 55, 2015, p.444-454, DOI 10.1007/s10464-0159723-1.

[32] LOMBARDI, P., GIORDANO, S., FAROUH, H. and YOUSEF, W.: Modeling the Smart City Performance, Innovation: The European Journal of Social Science Research 25: 2, 2012, p. 137-149.

[33] MACGREGOR, S.P., MARQUES-GOU, P. and SIMON-VILLAR, A.: Gauging Readiness for the Quadruple Helix: A Study of 16 European Organizations, Journal of Knowledge Economics, 1, 2010, p. 173-190.

[34] MARCHENKO, A.: Comparisons of Civic Engagement in Europe: Evidence from European Values Study, Slovak Journal of Political Sciences, Volume 14, No. 4, 2014, p. 331-361.

[35] MONDAK, J.J., HIBBING, M.V., CANACHE, D., SELIGSON, M.A. and ANDERSON, M.R.: Personality and Civic Engagement: An Integrative Framework for the Study of Trait Effects on Political Behavior, American Political Science Review Vol. 104, No. 1 February 2010, doi:10.1017/S0003055409990359.

[36] MOORE MCBRIDE, A. and MLYN, E.: Innovation Alone Won't Fix Social Problems, The Chronicle of Higher Education, 2015, http://www.chronicle.com/article/

InnovationAloneWont Fix/151551.

[37] MOY, P., MANOSEVITCH, E., STAMM, K. and DUNSMORE, K.: Linking Dimensions Of Internet Use And Civic Engagement, Journalism and Mass Communication Quarterly; Autumn 2005; 82, 3, 2005, p. 571-585.

[38] PADEL, S. and FOSTER, C.: Exploring the gap between attitudes and behaviour: Understanding why consumers buy or do not buy organic food, British Food Journal, Vol. 107 Iss: 8, 2005, pp. $606-625$.

[39] PANCER, M.S.: The Psychology of Citizenship and Civic Engagement, Oxford University Press, 2015.

[40] PUTNAM, R. D.: Bowling alone: America's declining social capital. Journal of Democracy, 6(1), 1995, pp. 65-78.

[41] QUINTELIER, E. and VAN DETH, J.W.: Supporting Democracy: Political Participation and Political Attitudes. Exploring Causality Using Panel Data, Political Studies, Volume 62, Issue S1, 2014, p. 153-171.

[42] REDDICK, C.G.: Citizen interaction and e-government: evidence for the managerial, consultative and participatory models, Transforming Government: People, Process and Policy, Vol. 5, No.2, 2011, pp. 167-184.

[43] SHAH, D., SCHMIERBACH, M., HAWKINS, J., ESPINO, R. and DONAVAN, J.: Nonrecursive models of Internet use and community engagement: questioning whether time spent online erodes social capital, Journalism and Mass Communication Quarterly; Winter 2002; 79, 4, 2002, p. 964-987. 
[44] TEMPLE, J.: Growth Effects of Education and Social Capital in the OECD Countries, OECD Economic Studies No. 33, 2001, pp. 57-101.

[45] TERLAU, W. and HIRSCH, D.: Sustainable Consumption and the Attitude-Behaviour-Gap Phenomenon - Causes and Measurements towards a Sustainable Development, 2015, file://C:/ Users/Administrator/Downloads/460-1537-1-PB.pdf.

[46] WAlLACE, C. and PICHLER, C.F.: More Participation, Happier Society? A Comparative Study of Civil Society and the Quality of Life, Soc Indic Res , 93, p.255-274, DOI 10.1007/s11205-008-9305-9, 2009.

[47] WARREN, A.M., SULAIMAN, A. and JAAFAR, N.I.: Social media effects on fostering online civic engagement and building citizen trust and trust in institutions, Government Information Quarterly, Vol.31, Iss.2, 2014, p. 291-301.

[48] WHITLEY, C.T. and YODER, S.D.: Developing social responsibility and political engagement: Assessing the aggregate impacts of university civic engagement on associated attitudes and behaviors, Education, Citizenship and Social Justice, Vol. 10(3), 2015. p. $217-$ 233.

[49] ZANOLI, R. and NASPETTI, S.: Consumer motivations in the purchase of organic food: a means-end approach, British Food Journal, vol.104, iss.8, 2002, pp. 643-653.

[50] Zhang, W. and Gearhart, S.: The Effects of Internet Use and Internet Efficacy on Offline and Online Engagement, Online Journal of Communication and Media Technologies Volume: 5 Issue: 4 October -2015. 